\title{
The Populist Dimension of Mediated Discourses About Corruption in Romania
}

\author{
Delia Cristina Balaban \\ (iD) ORCID: 0000-0003-3509-533X \\ Babes-Bolyai University, Romania
}

Mihnea S. Stoica

ORCID: 0000-0002-3295-9983

Babes-Bolyai University, Romania

\author{
Hanna Orsolya Vincze \\ (iD) ORCID: 0000-0002-0477-958X \\ Babes-Bolyai University, Romania
}

Iulia Medveschi

(iD) ORCID: 0000-0003-4345-2042

Babes-Bolyai University, Romania

\begin{abstract}
Understanding populism as a communication strategy (Aalberg et al. 2017) that is based on both messages and styles (Engesser et. al., 2017), the present research investigates the populist elements of political discourses articulating the subject of "corruption" in the context of the attempts to change the anti-corruption legislation by the Romanian government in 20172018. Based on audience preferences and on the density of political communication conducted by both political and media actors, the study conducted content analysis articles from three major Romanian TV-related news portals during February 2017 and May 1 - June 5, 2018 (N=548). In addition, computer-assisted content analysis was performed on social media posts of political parties $(\mathrm{N}=875)$ and the posts of their leaders $(\mathrm{N}=540)$. The research not only identified elements of populist political communication both in the content and the style of corruption-discourses but also reflected the polarization of the Romanian media system.
\end{abstract}

KEYWORDS: corruption, populist political communication, Romania, content analysis, Facebook.

\section{INTRODUCTION}

In recent years, the defining element of Romania's presence in international news media has been the issue of corruption. Recent attempts by the Romanian government to change the legislative framework impacting political corruption triggered unprecedented protests widely broadcast by national and international media. But even before this time, both national and international media reported widely on corruption in Romania. This issue was the focus of political 
campaigns for both parliamentary and presidential elections. For example, Traian Băsescu, the former Romanian president (2004-2015) ran on an anti-corruption platform in the 2004 elections. However, corruption is not a recent topic of media and political discourses. Defined in various ways, from pinpointing its meaning to technicalities of good governance or legal definitions of bribery to the outright moral decay of the body politic, it is a concept that has played a recurrent, if underappreciated role throughout Western political discourses (Buchan \& Hill, 2014).

Transparency International's 2018 Corruption Perceptions Index ranked Romania as 61, followed by Hungary (64) and Greece (67), to mention some of the countries from the region (Transparency International, 2018). Thus, from the perspective of international organizations such as Transparency International monitoring corruption perceptions in different countries, the level of corruption in Romania was not reported to be significantly higher than the level of corruption in other EU member states from the region.

As Romania was consolidating its democratic system after the collapse of communism, and as the country was approaching European integration, which eventually took place in 2007 , the issue of corruption emerged as increasingly relevant in the public opinion. The overall perception related to corruption was that of an all-encompassing process and widespread phenomenon, which greatly affected the lives of Romanian citizens under many aspects, ranging from quality of life and health to personal security. Studies point to the trigger of such perceptions as being the disproportionate focus of the media on corruption cases, which in turn reinforced the belief that such practices were inevitable to get by in Romanian society (Precupetu, 2007, p. 17). Most of the cases presented in the media involved medium or high-ranking politicians, who would later become the so-called "big fish" that in some cases ended up being prosecuted, trialed and even sentenced to prison. The widely shared belief was that corruption represented an outcome of systemic factors related to the ill-functioning of the transition economy, which often allowed sufficient space for shady deals, primarily based on inadequate privatizations, especially in the 1990's. Romania registered the slowest pace of privatization compared to all other former communist states. This situation favored corruption because it allowed sufficient time to develop illegal economic mechanisms that ensured state-owned companies would end up owned by "entrepreneurs" who were close friends of those in office (Popescu-Birlan, 1994, p. 376).

Another major factor that contributed to the situation was the functioning of the judicial system, which was often perceived as being under the strong influence of high-ranking politicians. The fight against corruption through strengthening the power of anti-corruption prosecutors has therefore emerged as a "sanitary" process of "cleaning up Romania" that promised to redress the 
economic and moral fabric of the Romanian society. Anticorruption emerged as a powerful electoral slogan in Romania during the elections held in the 2000's, both before and after the EU accession, but the political communication aspect had little to do with the on-the-ground reality, as Romania still struggled with high levels of corruption and dysfunctional public institutions (Tanasoiu \& Racovita, 2012, p. 243).

In January of 2017, the attempt by the Romanian Government to decriminalize certain corruption offenses through an emergency ordinance prompted some of the country's most extensive protests since the fall of communism. Surveys conducted during the events reflected that citizens protested not only to manifest their anger against this specific governmental decision, but primarily to exhibit their support for the fight against corruption in Romania (Stoica, 2017). Given the magnitude of the protests, which one evening attracted about half a million citizens on the urban streets of Romania, the events were highly mediatized internationally, with news outlets all over the world reflecting on what was happening in Bucharest and in other major cities. Reuters noted that those who were protesting were mostly concerned with what they perceived to be an abuse of power (Reuters, 2017), and the BBC reported that protests continued even after the Government had decided to repeal the ordinance (BBC, 2017). Protests lasted almost seven weeks, during which social media played a significant role in enabling political communication between the main actors involved (Mucundorfeanu, 2019).

\section{POPULIST POLITICAL COMMUNICATION, THE SUBJECT OF CORRUPTION, AND THE MEDIA}

Corruption, together with other topics such as immigration, regional identity, and crime were identified as political issues that are subjects of populist political communication in Western democracies (Taggart, 2017; Smith, 2010). As the number of studies dedicated to populism is rapidly growing, the concept can be sometimes confusing, given its overly stretched borders. Many scholars have considered populism to be nothing more than a style of communication, with an ideological framework that if it exists is highly flexible, if any at all (Taggart, 1996). Other authors consider populism to be a strategy that wins votes by appealing exclusively to the emotions of the electorate (Jagers \& Walgrave, 2007). However, more commonly, populism is referred to as a reaction against the establishment, doubled by a strong appeal to the People - as a sort of ultimate authority (Canovan, 1999).

The recent rise of populism across Europe needs to be understood in the context of today's highly media-centered politics that feeds on the communication 
of politicians who break the routine. Most of the time, populist leaders prove to be experts in simplifying the complexities of mainstream vernacula, therefore offering the media what it wants (Mazzoleni, 2008). The surge of populism is also the result of the increasing trend of personalizing politics, which media support when competing for audience share. This shifts the focus of citizens from debates over institutions, to discussions about the personality traits of politicians. Some political systems even favor the attention on politicians - as is the case in the USA and France (Kriesi, 2012). But neither is the situation new for Eastern Europe, which for many years has experienced the "presidentialization" of politics (Krouwel 2000). This offers the perfect context for populism.

Therefore, there are different approaches in literature towards populism: ideology centered (Mudde, 2004) and discourse centered (Hawkins, 2010). Some authors also emphasize the normative dimension of populism and consider it as both a threat and a corrective for democratic politics (Mudde \& Kaltwasser, 2012). According to Engesser, Fawzi and Larsson (2017), the different approaches on populism represent only different aspects of this phenomenon that do not exclude each other.

In terms of populism as an ideology, the literature identifies several types of populism, based on the combinations of four major elements: anti-elitism, restoring sovereignty, people centrism and exclusion of out-groups (Aalberg et al., 2017), which enables a four-fold typology of populism: (i) complete populism includes references to all four elements; (ii) excluding populism includes only references and appeals to the people and the exclusion of out-groups; (iii) antielitist populism includes references and appeals to the people and anti-elitism; and (iv) empty populism exclusively references and appeals to the people (Aalberg et al., 2017; Jagers \& Walgrave 2007; De Vreese et al., 2018).

The discourse-centered perspective views populism as a communication phenomenon, "a set of characteristics or elements of messages that have their roots in, or at least relate to, the aims, motivations and attitudes of political actors, the media or citizens" (Reinemann et al., 2017, p. 14). Populism is often seen as a communication style (Jagers \& Walgrave, 2007), as a political style (Moffitt, 2016) or as a political strategy (Weyland, 2001). Populist political communication is a narrative of crisis and threat or rhetoric using emotional statements and simplification (Moffitt \& Tormey, 2014; Taggart, 2017).

Research on populist discourses has focused on the content of communication, on its form, on motives and aims and on actors by analyzing their messages. Ernst et al. (2018) developed an instrument to analyze populist political communication applying three dimensions of populist ideology: people-centrism, antielitism and restoring popular sovereignty, combined with three dimensions related to communication style: negativity, emotionality and sociability. Populist political communication occurs in fragmented ways (Engesser et. al., 2017), thus 
a statement is populist if it combines at least one ideological "key message" and one populist "style element" (Ernst et al., 2018).

Our perspective on populism is in line with an approach, according to which populism is ,a characteristic of a specific message rather than a characteristic of an actor sending the message" (Rooduijn, de Lange \& van der Brug, 2014, p. 3). Previous research on populist political communication focused on identifying the issues that were subjects to this type of communication out of a corpus of political communication messages (Ernst et al., 2018; Ernst et al., 2017). By focusing on a single subject, the issue of corruption, we followed a different approach. We analyzed mediated messages about corruption in the context of the attempts to change the laws related to the fight against corruption in Romania and the massive protests that followed in January and February 2017 and May-June 2018, from the perspective of populist political communication.

Understanding populism as a communication strategy (Stanyer et. al., 2017) that is based on both messages and styles (Engesser et al., 2017), our objective was to identify elements of populist political communication related to content and to style in the media. We investigated how the subject "corruption" was presented in mediatized populist discourses along four dimensions: anti-elitism, restoring sovereignty, people centrism and exclusion (Aalberg et al., 2017).

(RQ1): What elements of populist content and populist style are present in the media coverage of government attempts to change the legal framework related to corruption?

Traditional media plays an important role for populist political communication (Esser et. al., 2017); there are certain affinities for populist political communication in specific types of media such as television and social media (De Vreese et al., 2018). The relationship between media and populism is driven by a logic of supply and demand. Populist politicians exploit the media's proclivity towards anything that "breaks the routine" in political arenas. Populist leaders and movements often seem to rely on some sort of "media complicity" (Mazzoleni, 2008). News values of populist actors influenced the presence of populist actors in journalistic contents. Several studies note that journalistic interference is a filter for populist political communication by the media and through the media (Esser, Stępińska \& Hopmann, 2017).

Romania has a hybrid media system (Chadwick, 2013) with a large variety of media channels and the continued prominence of television in the media diet of large segments of the politically active audience. According to Hallin and Mancini's comparative model of media systems (2004), the Romanian one can be described as a polarized-pluralist system (Balaban, 2007). A varied media landscape and media distribution developed after 1990 and a parallelism between political parties and media institutions developed in the 1990's (Balaban, 2003). In the last two decades reading online versions of print media has become 
popular in Romania, so some newspapers have ceased to be printed, retaining only their digital version. Romanian political communication is performed especially on the five national news TV channels (Romania TV, Antena3, Digi24, $B 1 T V$, and Realitatea $T V$ ), characterized by strong political parallelism and polarization (Balaban 2007). At the same time, several of these televisions' websites function as news portals, and are among the most highly ranked online news sources based on their traffic.

As media is the key link between political actors and the public, our research focused on populist political communication through the media and by the media. Thus, we included both populist statements delivered by politicians through the media and populist messages delivered by journalists (Esser et. al., 2017; De Vreese et al., 2018). In line with this we formulated the following research question: (RQ2) How does the polarization (political parallelism) of the media system mediate the articulation of populist messages related to corruption?

Populism has developed a special relation to the "new media galaxy" (Keane, 2013) and its new forms of algorithmic gatekeeping (De Vreese et al., 2018). Social media presents particular opportunity structures for populist actors, as it offers a direct connection to audiences, allows the creation of homogeneous groups often with the exclusion of dissenting voices, favors a simplified and emotionalized style, all elements that have also been identified as central to populist communication logics (Engesser et. al., 2017). Researchers have analyzed populist political communication on social media (Ernst et al., 2017), in the Netherlands (Hameleers, Bos \& De Vreese, 2016), and in Hungary and Italy (Moffitt, 2016).

The preference of young people for online media consumption has brought about significant changes to the Romanian media landscape as well, as news consumption via social media has been steadily increasing. Apart from news portals, the online media diet of the Romanian news consumers is defined by Facebook (Balaban et. al., 2018; Mucundorfeanu, 2019). As elsewhere in Europe, political communicators in Romania have turned to the internet not only to avoid media gatekeepers and directly address audiences but have also been successfully employing social media to set the news agenda (Mucundorfeanu, 2019). At the same time, protest movements also made extensive use of social media platform for organizational as well as expressive purposes, including identity (Burean. 2019). Hence our third research question: (RQ3) What are the populist discursive patters of social media posts of Romanian political parties and leaders in the period of the protests? 


\section{METHODOLOGY}

Based on audience preferences and on the density of political communication conducted by both political and media actors, the study conducted content analysis on a sample of articles ( $\mathrm{N}=548)$ from three Romanian TV-related news portals - Realitatea.net, Digi24.ro, Antena3.ro. The time frame January - February 2017 and May 1 - June 5, 2018 corresponded to the large-scale protests related to the proposed changes to anti-corruption measures. The choice of the news portals is based on political parallelism: Antena3.ro is close to the PSD (The Social Democrat Party, governing at the time), Realitatea.net is close to PNL (The National Liberal Party, in opposition at the time) and Digi24.ro is considered to have a neutral position. A keyword search of corruption and reform of justice system of the three TV-related news portals produced during the two time frames found 548 articles: antena3.ro $(n=230)$, realitatea.net $(n=192)$ and digi24.ro $(n=126)$.

We operationalized populist political communication as the public communication of core components of populist ideology in terms of content and style (14 items, $\alpha=.741, M=0.20, S D=0.13$ ). We adapted Ernst et al.'s (2018) populist political communication scale to measure populist communication in general to populist political communication in our study specific topic. The presence or absence of those elements was manually coded as dummy variables by two coders. An inter-coder reliability test was performed on 55 articles, $10 \%$ of the total material. A suitable reliability of Krippendorff' $\alpha=.703$ for the means of the 15 items describing populist political communication was calculated.

Within the 14 items, 3 groups referred to populist content: anti-elitism ( 3 items, $\alpha=.71, M=0.30, S D=0.24$ ), people-centrism (3 items, $\alpha=.71, M=0.02, S D=0.10$ ) and restoring sovereignty ( 2 items, $r s b=.86, M=0.30, S D=0.15$ ), totaling 8 items $(\alpha=.76, M=0.13, S D=0.12)$. Style elements such as negativity, emotionality, and sociability that are associated to populist ideology were coded as populist style (6 items, $\alpha=.62, M=0.30, S D=0.16$ ).

We also measured if the article expressed a position towards the modification of the laws against corruption using a single item 7-point Likert scale from "strongly not in favor" to "strongly in favor" $M=4.02, S D=2.61$. In this case, the inter-coder reliability test showed a suitable value: Krippendorff' $\alpha=.789$.

We also triangulated our findings concerning the dimensions of the anti-corruption populist media messages with an analysis of Facebook posts of the main Romanian political parties and political leaders during the same period. The analysis of Facebook posts of political parties and their front men will reveal mostly populist political communication through the media. Computer assisted content analysis of all Facebook posts of parliamentary parties and their leaders $(N=1203)$ : PSD ( $n=37), \operatorname{ALDE}(n=159)$, PNL $(n=184)$, PMP $(n=198)$ USR $(n=151)$, 
Liviu Dragnea ( $n=27)$, Călin Popescu-Tăriceanu ( $n=165)$, Ludovic Orban $(n=11)$, Traian Băsescu ( $n=68)$, Dan Barna ( $n=130)$, Nicușor Dan $(n=73)$. A further parliamentary party, the Democratic Alliance of Hungarian in Romania was not included in the analysis for methodological reasons, as most posts were in Hungarian, and our methodology was not appropriate for a multilingual corpus. The corpus was collected using API interrogation of the respective Facebook pages. Discursive patterns on social media were analyzed by mapping associations of pages of the parties and their leaders with keywords. The keywords were defined using computational corpus linguistics techniques. The corpus of the texts of posts was compared with a reference corpus of Romanian-language foreign news, to find words the occurrence of which is significantly higher in the Facebook corpus than in the reference corpus. All keywords were significant above $p>.001$, based on their LogLikelihood values. Keywords were identified and statistics calculated using LancsBox (Brezina et al., 2018). The resulting list of keywords was used to create keyword codes by grouping word forms together. Co-occurrences of keyword-codes and source pages were mapped using KHcoder (Higuchi, 2001). Thus, our paper uses a mixed-methodology, which combines statistical analyses of manual content analysis with computational linguistics.

\section{FINDINGS AND DISCUSSION}

Descriptive statistics performed on the results of media content analysis showed that overall, the anti-elitism dimension $(M=0.30, S D=0.24)$ is mostly represented in the media coverage compared to restoring sovereignty $(M=0.03, S D=0.15)$, and people centrism $(M=0.02, S D=0.10)$. Media coverage in general was populist much more in terms of style $(M=.30, S D=.16)$ than in terms of populist content $(M=.13, S D=.14)$. Additional information on descriptive statistics is provided in Table 1.

Table 1. Descriptive statistics for populist political communication

\begin{tabular}{l|c|c|c|c|c|c}
\hline \multicolumn{1}{c|}{ Dimension } & Variable & N & Min & Max & Mean & $\begin{array}{c}\text { Standard } \\
\text { Deviation }\end{array}$ \\
\hline \multirow{3}{*}{ Anti-elitism } & Discrediting the elite & 548 & .00 & 1.00 & .08 & .27 \\
\cline { 2 - 7 } & Blaming the elite & 548 & .00 & 1.00 & .75 & .43 \\
\cline { 2 - 7 } & Detaching the elite & 548 & .00 & 1.00 & .07 & .26 \\
\hline \multirow{3}{*}{\begin{tabular}{c} 
People centrism \\
\cline { 2 - 7 }
\end{tabular}} & Stressing virtutes & 548 & .00 & 1.00 & .01 & .09 \\
\cline { 2 - 7 } & Praising achievements & 548 & .00 & 1.00 & .01 & .10 \\
\cline { 2 - 7 } & $\begin{array}{c}\text { Stating a monolithic } \\
\text { people }\end{array}$ & 548 & .00 & 1.00 & .03 & .17 \\
\hline
\end{tabular}




\begin{tabular}{|c|c|c|c|c|c|c|}
\hline Dimension & Variable & $\mathbf{N}$ & Min & $\operatorname{Max}$ & Mean & $\begin{array}{l}\text { Standard } \\
\text { Deviation }\end{array}$ \\
\hline \multirow{2}{*}{$\begin{array}{l}\text { Restoring } \\
\text { sovereignty }\end{array}$} & $\begin{array}{c}\text { Demanding popular } \\
\text { sovereignty }\end{array}$ & 548 & .00 & 1.00 & .02 & .15 \\
\hline & Denying elite sovereignty & 548 & .00 & 1.00 & .03 & .17 \\
\hline \multicolumn{2}{|c|}{ Populist content } & 548 & .00 & 1.00 & .13 & .14 \\
\hline \multirow{2}{*}{ Negativity } & Negativism & 548 & .00 & 1.00 & .68 & .47 \\
\hline & Crisis rhetoric & 548 & .00 & 1.00 & .89 & .32 \\
\hline \multirow{2}{*}{ Emotionality } & Emotional tone & 548 & .00 & 1.00 & .05 & .23 \\
\hline & Patriotism & 548 & .00 & 1.00 & .03 & .16 \\
\hline \multirow{2}{*}{ Sociability } & Colloquialism & 548 & .00 & 1.00 & .09 & .29 \\
\hline & Intimization & 548 & .00 & 1.00 & .02 & .15 \\
\hline \multicolumn{2}{|c|}{ Populist style } & 548 & .00 & 1.00 & .26 & .14 \\
\hline \multicolumn{2}{|c|}{ Populist index } & 548 & .00 & 1.00 & .20 & .13 \\
\hline
\end{tabular}

Source: Authors

Aiming to see the differences between news portals regarding populist content and style, we conducted a series of one-way ANOVA. For populist content we found no significant differences between the publications regarding antielitism $F(2,545)=0.90, p=.407, \eta 2=.003$, also no significant differences regarding people-centrism $F(2,545)=2.261, p=.105, \eta 2=.008)$, and no significant differences regarding restoring-sovereignty $F(2,545)=1.84, p=.16, \eta 2=.007)$. When analyzing populist content of the 8 items there are significant difference between publications $F(2,545)=3.50, p=.031, \eta 2=.013$. The Post-hoc pairwise comparison using Dunnett T3 correction in the instance of a positive Levine test showed significant differences only between antena 3 and realitatea.net $p=.026$. There are no significant differences between digi24.ro and anten3.ro $p=.582$ nor between digi24.ro and realitatea.net $p=.972$. Antena3.ro have the highest populist content among the three publications.

Regarding populist style, there are significant differences between the publications $F(2,545)=10.86, p<.001, \eta 2=.038)$ and a Post-hoc pairwise comparison using Dunnett T3 correction in the particular case of a positive Levine test, showed significant differences between antena3.ro and realitatea.net $p<.001$ and also between anten3.ro and digi24.ro $p<.001$. There were no significant differences between realitatea.net and digi24.ro $p=.997$. Both antena3.ro and realitatea.net have communicated in a higher populist style than digi24.ro.

The position of the publications antena3.ro $(M=4.32, S D=2.40)$, realitatea.net $(M=3.86, S D=2.66)$, and digi24.ro $(M=3.70, S D=2.87)$ regarding the modification of the laws against corruption was not significantly different according to the results of a one way ANOVA $F(2,545)=2.87, p=.058, \eta 2=.010)$.

Our findings indicate that populism characterized virtually all major political actors that represented the subject of our study, which means that populist 
communication was pervasive during the anti-corruption protests in Romania in 2017 and 2018. Most of them referred to anti-elitism, but references to people-centrism and to restoring sovereignty were also often used. We selected some illustrative examples of populist content through the media formulated by politicians from the political parties:

'Other state institutions (DIICOT, ANI, ANAF) are involved in huge corruption scandals, with files prepared by prosecutors, some with a certain perfume of power. Here is the main source of corruption in Romania today! Those appointed to run the institutions exercise discretionary power and try to control those elected by the people.' (Popescu-Tariceanu, 2017a).

'Not only the stupidity and corruption of politicians and officials have squandered public money and blocked the development of the country, as we have heard for many years. But also the corruption and immunity of the System made up of former Secret Services bosses, officers, prosecutors and judges or heads of state power institutions. The time has come to pay for all the harm done!' (Udrea, 2018).

Political discourses depicted various heads of institutions as conspiring elites who seek to undermine the will of the citizens. Amongst these elites are "prosecutors", "judges", "heads of intelligence agencies", all of whom work together to strengthen a "minority dictatorship" that decides not only in the name of the People, but instead of the People or even against the People. The absolute symbol of elitism represented (both then, and for quite a long period afterwards) the so-called "parallel state", a political construct approximating the "deep state". A scaremongering concept, the "parallel state" was described by Liviu Dragnea, former leader of the Romanian Social-Democrats as "a system that uses state institutions in an illegal way, outside and in parallel with the freedoms and the will expressed in voting" (Dragnea, 2018), "an abject fraternity, a contract that wants to get democracy out of the game" (Dragnea, 2018). Moreover, the President of the Romanian Senate accused the acting President of relying on "occult instruments of power" (Popescu-Tăriceanu 2017b), that are influenced by shady NGOs funded by George Soros.

"Dear Romanians from all over the country, the right of the Romanians is holy, we cannot accept anyone to confiscate the vote of the Romanians. Justice, justice, truth everywhere, in institutions. We cannot live with a minority dictatorship." (Vrânceanu-Firea, 2018).

People-centrism was sometimes marked by appealing to religion, granting the People an aura of holiness: "the right of Romanians is holy" (Vrânceanu-Firea, 
2018). Moreover, the political discourse appeals to strategies of strongly personalizing the experiences of so-called "innocent" citizens who are depicted as having fallen victims to the illegal practices of the judicial system. Therefore, such people are "souls" who suffer social or even physical degradation as a result of undeserved imprisonment.

\begin{abstract}
"That is why the Romanian people are called to judge, to pronounce themselves and to express their will. All Romanians with voting rights. Both those who protested in the streets and those who did not. All Romanians, regardless of political options. And their will, resulting from the vote given in the referendum, will be sovereign to us all. Let us therefore give the word of the sovereign people!" (Turcan, 2017).
\end{abstract}

Politicians in both the ruling party and the opposition scored high on the populist dimension of restoring sovereignty, asking for the will of the "sovereign People" to be respected, regardless of whether they have opted to protest on the streets around the country or to stay at home.

We triangulated the results of the media content analysis by looking at social media media discourses of the main political actors, i.e., parliamentary parties and their leaders using methods of computational linguistics.

The list of keywords include terms that designate issues central to the debate around the reform of the justice system, proposed by the governing coalition, and more general political issues like the budget, pensions or the voting system. Figure 1 shows that in the period investigated, keywords related to corruption and crime were central to the communication of USR, a party which ran on an anti-corruption platform. The governing PSD-ALDE coalition's messages centred on the relationship between the institutions of the state (with the alleged abuses being the reason for the proposed changes of the justice system that triggered the protests), while PNL focused on economic issues, and PMP on the voting system. The keywords with the highest commonality are referenences to the country and the people: 
Figure 1. Party - keyword co-occurrences of Facebook posts

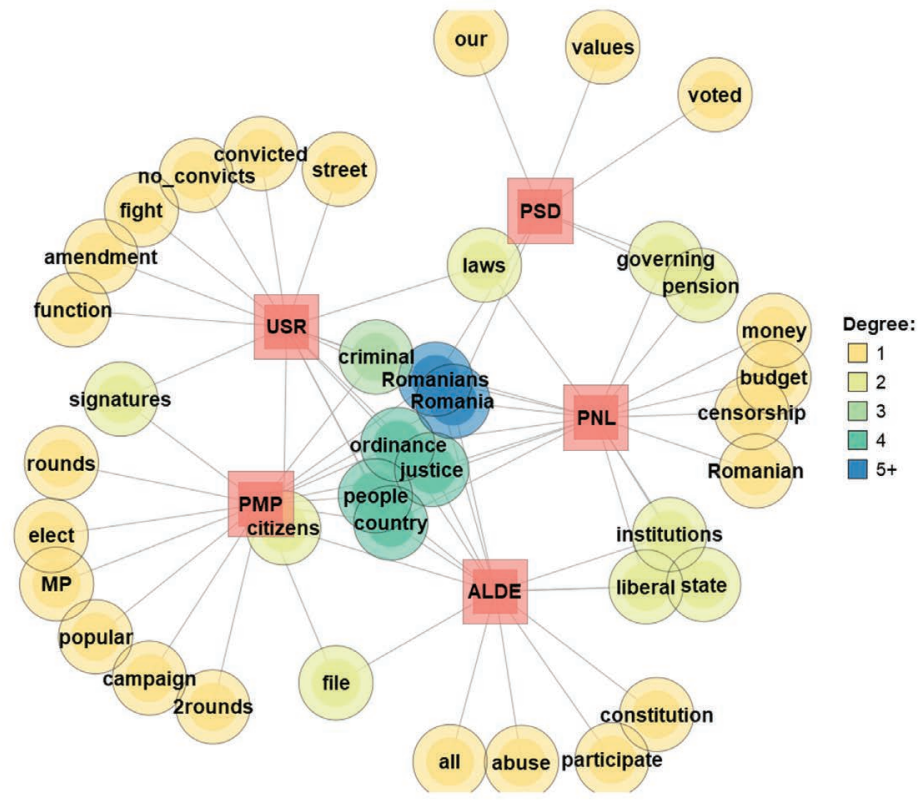

Ernst et al. (2018) argue that there are issues in political communication with higher and lower affinity with populist messages: immigration, regional identity, corruption and crime, integration, and economic hardship. Of these topics, our issue-specific keywords relate to corruption, crime and economic issues. However, a hierarchical cluster analysis of the keywords showed that the issue specific ones like institutions of the state, corruption, the voting system or the budget, all cluster together with further keywords that frame them in populist terms. They do so by appealing to the style elements of negativism, crisis rhetoric, emotional tone, dimensions, all of which Ernst et. al. (2018) emphasize, or references to a collective "we" or people, who are central to the so-called style of empty populism (See Figure 2 in the Annex).

Examining in context, the issue specific keywords provide us with discursive examples of populist framings. Elections and voting, a major topic of PSD is framed in terms of the promise of a better life, casting the president as an enemy of the people:

"The president does not understand that the electoral campaign is over, that the elections have been won by someone else and with this game of delays is keeping Romanians away from a better life!" [post by PSD on 2017-01-28]

The proposed reform of the justice system is cast as a fight against occult elites: 
"we need to continue our fight until the healthy force of democratic, legitimate organizations, elected by you citizens of Romania, will prevail over the sick forces, the occult forces that have grabbed our country." [post by ALDE, 2018-06-10].

The proposed elections in two rounds, a major topic of PMP is cast as a means to counteract "the profound suffering of democracy" (post by PMP, 2018-0604), an example of absolutist rhetoric in the sense Ernst et al. (2018) propose, as something preposterous and unbearable (p. 170). A proposed reform of the pension system is recurrently cast in posts by PNL as "the robbery of the century." (post by PNL, 2018-05-21):

\footnotetext{
"The government employs the tactic of a pickpocket, caught in the act, telling you what you can see with your own eyes is not true: it is not him with his hand in your wallet, in your pocket, but in fact it's your hand." [post by PNL, 2018-05-28]
}

The central slogan of the anti-corruption protests was "thieves in the night", referring to the late-night adoption of an ordinance modifying anti-corruption laws, thus becomes a transferrable element of political rhetoric.

\section{CONCLUSIONS}

The issue of corruption contributes to defining the four dimensions of the mediatized populist discourses along the political cleavages in the media landscape. The starting point is recognizing the characteristics of this ideology and the basic populist categories, such as the Manichean perception of society as divided into two separate, internally homogeneous groups and antagonistic camps: "the elite" and "the people" (Mudde, 2004). Anti-elitism populist content was identified in the analyzed articles. This dichotomous division valorizes the category "us", i.e., the people, as positive, and the category "them" (elite) as negative. In other words, the essence of populism is anti-elitism - an attitude of opposition to all those in power (political parties, officials, but also supranational institutions and organizations).

The polarization of the media system was reflected in the way the three analyzed publications communicated with respect to the attempt to change the laws. Elements of populist political communication both in content and in style were identified in the media communicating on corruption and on the attempts to change the laws to fight corruption. Among the three dimensions: anti-elitism, people centrism and restoring sovereignty, anti-elitism was much more present. 
Representatives of the Romanian judicial system were mostly portrayed as the elites that have fought against changing the laws against corruption. The populist style was identified by all the three publications that we analyzed. This can be explained by all three publications did identify the situation as a crisis and communicated in a more negative way. Similarly, even though issue-specific keywords of social media posts differ between the main political actors, these issues are all framed making use of elements of populist style.

From the general perspective of the research on populist political communication, the innovative perspective of the present paper is that it analyzed populist political communication using applied instruments that were already tested (Ernst et al., 2018), on the specific issue of "corruption". Previous research pointed out the affinity of the topic "corruption" to populist political communication (Smith, 2010; Taggart, 2017).

The limits of our research consisted of its descriptive nature. Being unable to separate between populism by the media and through the media is also a limit of our research. This is an aspect that must be addressed in future research. Even if we analyzed articles from the news portals related to the three news televisions realitatea.net, antena3.ro and digi24.ro, most of the populist political communication performed by Romanian news TVs was not revealed. An analysis of talk shows that were and are still broadcasted for several hours - daily - would have contributed to a better image of the populist political communication related to "corruption" in Romania. This can also be the subject of future research.

\section{REFERENCES}

Aalberg, T., Esser, F., Reinemann, C., Strömbäck, J., \& de Vreese, C.H. (Eds.), (2017). Populist political communication in Europe. Routledge.

Balaban, D.C., Constantinescu, S., \& Mustãțea, M. (2018). Social media networks unveiled. Mapping the Romanian and German youth. Journal of Media Research, 11, 3(32), 35-44.

Balaban, D.C. (2003). Die Entwicklung der Fernsehlandschaft nach der Wende in Rumänien. In D. Busch, I. Panasiuk, \& H. Schröder (Eds.), Medientrans》 formationsprozesse, Gesellschaftlicher Wandel und Demokratisierung in Südosteuropa (pp. 315-322). Peter Lang.

Balaban, D.C. (2007). Wenig lesen, viel fernsehen. Strukturelle Faktoren der Mediennutzung in Rumänien. Münchner Beiträge Zur Kommunikationswissenschaft. 8 (August), <http://epub.ub.uni冈muenchen. de/archive/00002015/>

BBC. (2017). Romanian protesters not backing down after decree repeal. https://www.bbc.com/news/ world-europe-38876134

Brezina, V., Timperley, M., \& McEnery, T. (2018). \#LancsBox v. 4.x [software]. http://corpora.lancs. ac.uk/lancsbox

Buchan, B., \& Hill, L. (2014). An intellectual history of political corruption. Palgrave Macmillan. 
Burean, T. (2019). Democrats on the streets. Drivers of student protest participation in Romania. PArtecipazione e COnflitto. 12(1), 22-42.

Canovan, M. (1999). Trust the people! Populism and the two faces of Democracy. Political Studies, $47(1), 2-16$.

Chadwick, A. (2013). The hybrid media system. Oxford University Press.

de Vreese, C.H., Esser, F., Aalberg, T., Reinemann, C., \& Stanyer, J. (2018). Populism as an expression of political communication content and style: A new perspective. The International Journal of Press/ Politics, 23(4), 423-438.

Dragnea, L. (2018). Sfârșit de miting PSD. Peste 100.000 de oameni au ascultat, fără interes, discursurile liderilor, media release, REALITATEA.NET, 08 June https://www.realitatea.net/stiri/politica/miting-psd-liviu-dragnea-piata-victoriei_5dcc9269406af85273d7054a

Engesser, S., Fawzi, N., \& Larsson, AO. (2017). Populist online communication: Introduction to the Special Issue. Information, Communication and Society, 20(9), 1279-1292.

Ernst, N., Engesser, S, Büchel, F., Blassnig, S., \& Esser, F. (2017). Extreme parties and populism: an analysis of Facebook and Twitter across six countries. Information, Communication \& Society, 20(9), 1347-1364.

Ernst, N., Esser, F., Blassnig, S., \& Engesser, S. (2018). Favorable opportunity structures for populist communication: Comparing different types of politicians and issues in social media, television and the press. The International Journal of Press and Politics, 24(2), 165-188.

Esser, F., Stępińska, A., \& Hopmann, D. (2017). Populism and the media: Cross-national findings and perspectives. In T. Aalberg, F. Esser, C. Reinemann, J. Strömbäck, \& C.H. de Vreese (Eds.), Populist political communication in Europe (pp. 365-380). Routledge.

Hallin, D.C., \& Mancini, P. (2004). Comparing media systems. Three models of media and politics. Cambridge University Press.

Hameleers, M., Bos, L., \& De Vreese, C.H. (2016). They did it: The effects of emotionalized blame attribution in populist communication. Communication Research, 24(2), 870-900.

Hawkins, K.A. (2010). Venezuela's Chavismo and populism in comparative perspective. Cambridge University Press.

Higuchi, K. (2001). Kh Coder: A free software for quantitative content analysis or text Mining., <http:// khc.sourceforge.net/en>

Jagers, J., \& Walgrave, S. (2007). Populism as political communication style: An empirical study of political parties' discourse in Belgium. European Journal of Political Research, 46(3), 319-345.

Keane, J. (2013). Democracy and media decadence. Cambridge University Press.

Kriesi, H. (2012). Personalization of national election campaigns. Party Politics, 18(6), 825-844.

Krouwel, A. (2000). The presidentialisation of East-Central European countries. ECPR Joint Sessions workshop on the presidentialisation of parliamentary democracies. Copenhagen, Denmark.

Mazzoleni, G. (2008). Populism and the media. In D. Albertazzi., \& D. McDonnell (Eds.), Twenty-first century populism: The spectre of Western European democracy (pp. 49-64). Palgrave Macmillan.

Moffitt, B., \& Tormey, S. (2014). Rethinking populism: Politics, mediatisation and political style, Political Studies, 62(2), 381-397. 
Moffitt, B. (2016). The global rise of populism. Performance, political style, and representation, Standford University Press.

Mucundorfeanu, M. (2019). The online communication of political parties and their leaders reacting to street protests in Romania. Journal of Media Research, 12(34), 50-73.

Mudde, C. \& Kaltwasser, C.R. (2012). Populism in Europe and the Americas, Cambridge University Press.

Mudde, C. (2004). The populist zeitgeist. Government and opposition. Government and Opposition, 39 (4), 542-563.

Popescu-Birlan, L. (1994). Privatisation and corruption in Romania. Crime, Law and Social Change, 21(4), 375-379.

Popescu-Tariceanu, C. (2017a). Sinteza zilei. Tăriceanu: Decizia CCR pune lucrurile în ordine. Sunt instituții scăpate de sub control/ Soros a dat 11,2 mld dolari la ONG-uri, media release, Antena3. ro. 28 February. https://www.antena3.ro/politica/tariceanu-vrea-demisia-lui-kovesi-al-doilea-omin-stat-vine-la-sinteza-zilei-401721.html

Popescu-Tariceanu, C. (2017b). Tăriceanu, către PNL: “Vă aduc aminte cum acționau politrucii din perioada stalinistă...", media release, Realitatea.net, 08 February. https://www.realitatea.net/stiri/ politica/tariceanu-catre-pnl-va-aduc-aminte-cum-actionau-politrucii-din-perioada-stalinista_5dcc9246406af85273d530ae

Precupetu, I. (2007). Corruption in Romania: First steps towards a grounded theory of corruption. Crime and Culture: Discussion paper series, 4, 2-39.

Reinemann, C., Aalberg, T., Esser, F., Strömbäck, J., \& de Vreese, C.H. (2017). Populist political communication. Toward a model of its causes, forms, and effects. In C. Reinemann, J. Stanyer, T. Aalberg, F. Esser., \& C.H. de Vreese (Eds.), Populist political communication in Europe (pp. 12-28). Routledge.

Reuters (2017). Tens of thousands rally in Romania against planned emergency Decrees. https://www. reuters.com/article/us-romania-protests/tens-of-thousands-rally-in-romania-against-plannedemergency-decrees-idUSKBN15D118

Rooduijn, M., de Lange, S. L., \& van der Brug, W. (2014). A populist zeitgeist? Programmatic contagion by populist parties in Western Europe. Party Politics, 20(4), 565-575.

Smith, J. M. (2010). Does crime pay? Issue ownership, political opportunity, and the populist right in Western Europe. Comparative Political Studies, 43(11), 1471-1498.

Stoica, M.S. (2017). Survey evidence: why people are protesting in Romania, LSE

European Politics and Policy (EUROPP) Blog. https://blogs.lse.ac.uk/europpblog/2017/02/08/survey-evidence-protests-romania/

Taggart, P. (2017). Populism in Western Europe. In C.R. Kaltwasser, P. Taggart, P. O. Espejo, \& P. Ostiguy (Eds.), The Oxford handbook of populism. Oxford.

Taggart, P. A (1996). The new populism and the new politics. In The New Populism and the New Politics. New Protest Parties in Sweden in a Comparative Perspective (pp. 11-46). Palgrave Macmillan.

Tanasoiu, C., \& Racovita. M. (2012). Post-accession (anti-) corruption record in Romania and Bulgaria, L'Europe en Formation, 2, 243-263.

Transparency International. (2018). Corruption Perceptions Index 2018. https://www.transparency.org/ en/publications/corruption-perceptions-index-2018 
Turcan, R. (2017). Raluca Turcan: Să dăm cuvântul poporului suveran!, media release, Antena3. ro. 13 February. <https://www.antena3.ro/politica/raluca-turcan-sa-dam-cuvantul-poporului-suveran-399691.html>

Udrea, E. (2018). Elena Udrea, reacție surprinzătoare despre risipirea banilor publici. media release. REALITATEA.NET. 05 June. https://www.realitatea.net/stiri/actual/elena-udrea-risipirea banilor_5dcc9269406af85273d70362

Vrânceanu Firea, G. (2018). Mitingul PSD s-a încheiat. Piața Victoriei s-a luminat cu lanterne. Cele mai importante mesaje transmise de liderii Coaliției (FOTO+VIDEO., media release. Antena3.ro. 09 June. https://www.antena3.ro/actualitate/miting-psd-mobilizare-masiva-sute-de-mii-de-oameni-la-miting-tariceanu-trebuie-sa-ne-luam-472942.html

Weyland, K. (2001). Clarifying a contested concept - populism in the study of Latin American politics. Comparative Politics, 34(1), 1-22. 


\section{ANNEX}

Figure 2. Keyword clusters

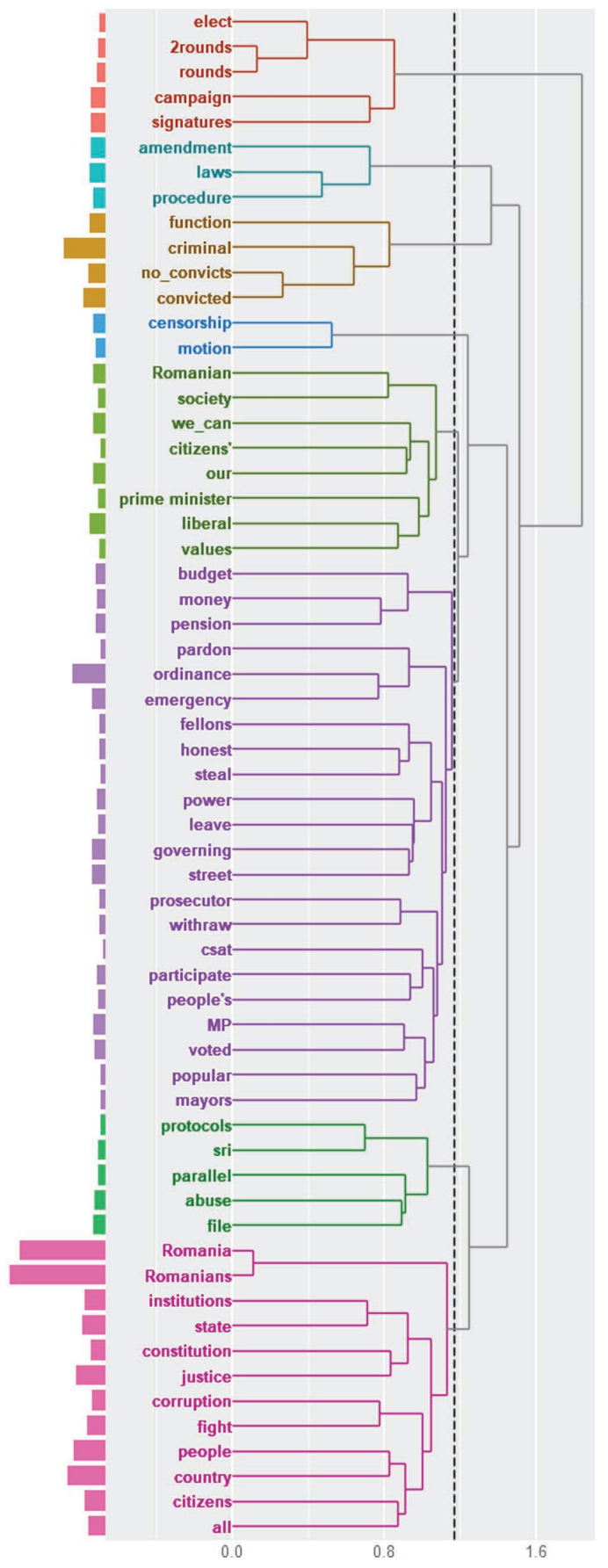

